\title{
CONDITIONS FOR THE PROTECTION OF HUMAN RIGHTS WHILE COVID-19, LEGAL PRINCIPLES AND ADMINISTRATIVE BARRIERS IN UKRAINE
}

\author{
Chystokletov Leontii Grugorovych ${ }^{1}$, Tkachuk Taras Yuriiovych ${ }^{2}$, Yarmol Liliia \\ Volodymyrivna $^{3}$, Shvets Yuriy Yuriyovich ${ }^{4}$, Yosyfovych Danylo Igorovych ${ }^{5}$ \\ ${ }^{1}$ doctor of law, professor, Professor of Department of Administrative and Informational Law Educational and \\ Scientific Institute of Law and Psychology Lviv Polytechnic National University, \\ ${ }^{2}$ doctor of law, docent, Educational and Scientific Institute of Information Security of the Security Service of \\ Ukraine, \\ ${ }^{3}$ doctor of Law, docent, associate professor at the department of theory, history and philosophy of law \\ Educational and Scientific Institute of Law and Psychology Lviv Polytechnic National University \\ ${ }^{4}$ Associated professor, Institute of Control of Science RAS Financial University under the Government of \\ Russian Federation \\ ${ }^{5}$ Candidate of Law, Docent, Head of the Department of Administrative Law and Administrative Procedure \\ Lviv State University of Internal Affairs
}

\begin{abstract}
The article describes both the administrative and legal principles of human rights protection in the context of the spread of coronavirus, which is used in Ukraine and all over the world on the basis of theoretical and practical methods. In this regard, the question of the efficiency of the measures to lessen the spread of the virus, made in connection with the new tasks of the state authorities and, first of all, health authorities, without violating the basic rights of the people becomes relevant. It is proved that the legal analysis of the ratification of international and domestic regulations indicates extraordinary opinions on the issue of ensuring human rights in an emergency relative to the struggle with the infection. Basing on international and national practice, attention is grabbed to the administrative and legal principles of ensuring medical confidentiality during the pandemic. It is shown that the disclosure of medical secrets is allowed in cases of suspicion of the patient intending to commit a crime or on the basis of a decision of a court. Current work provides guidelines directed at enhancing the measures for protecting peoples'
\end{abstract}

rights in the situation of suppressing the spread of COVID-19.

Keywords: medical secrecy, human rights, COVID-19, emergency, healthcare, quarantine.

\section{Introduction}

With the occurrence of COVID-19, the international community is going through a huge ordeal that endangers the health and lives of billions of people more than ever. It is worth noting the words of Pope John Paul II, who said that the functioning of medical workers is of great importance because they work to save other lives. This is the incarnation of a strong human and Christian destiny, which comprises not only technical operations but also self-abnegation and love for one's neighbor. This is a "form of Christian witness", their job forces them to be keepers of life [1]. In connection with the pandemic, quarantine measures have been implemented in plenty of countries all over the world, including Ukraine. Based on the international and domestic practice, the restriction of fundamental human rights and freedoms by releasing new norms and sanctions to bring to justice for violations of quarantine norms 
and rules accompanies the implementation of such a special regime as quarantine; hence, during such a period, the operations of state authorities aimed at ensuring the sanitary and epidemic well-being of society when intervening in securing of human rights should be more sensible, weighted, and directed to their ensuring.

\section{The purpose and objectives of the study.}

The research is directed to enhancing and formation of the main regulations of administrative and legal principles for the protection of human rights in the situation of the spread of COVID-19 in Ukraine. To achieve this goal, the following tasks were solved:

- to study and analyze normative and literary data and formulate the problem of human rights protection in the situation of spread of the COVID-19 pandemic;

- to justify the methodology and approach to solving the problem of compliance with the administrative and legal principles of human rights protection;

- to outline the administrative and legal principles of protection and grounds for disclosure of medical secrets in the context of the COVID-19 pandemic;

- to study the administrative and legal basis for the observance of human and civil rights in the sphere of business and problems of punishment for violations of quarantine rules.

\section{The study and analysis of normative and literary data and the formulation of the problem of human rights protection in the situation of spread of COVID-19 in Ukraine}

Since its creation, humanity has always undergone pandemics. Scientists began their research in the middle of the XVIII century. It is known that the One of the features of the spread of COVID-19 in Ukraine and the world is the rapid increase in the number of patients who suffer from the virus asymptomatic, being a source of infection for first coronavirus infection appeared in the 1960s; in 2002, it was discovered in China (the so-called "SARS" (Severe Acute Respiratory Syndrome related to coronavirus)), and ten years later, in 2012, it began its spread into the Middle East. The virus is called "MERS" (Middle East Respiratory Syndrome). It killed about $35 \%$ of all the infected people. It wasn't until 1960 that epidemiologist William Kermak and biochemist Anderson McKendrick created the first model to systematically predict the origin, spread, and resistance to viruses. The content of this model is based on universal equations and consists of dividing the population into three groups: vulnerable, infected, and recovering; however, according to the mutation of the virus, the proposed model for struggling with the COVID-19 disease turned out to be incomplete and inefficient. Nowadays, a disproportionate number (approximately 60\%) of African Americans die from the virus. They live more densely and have less access to health care. 30 million do not have health insurance out of the 328 million people living in America, and the current health policy does not fully cover coronavirus treatment for $23 \%$ of the population. Its cost, due to what the experts say, varies from $\$ 42,486$ to $\$ 74,310$. As a result, a lot of Americans have died, being afraid not to find medical care because they were not able to pay for it. There is no statistics, but local experts name this case "extremely likely" [2]; in addition, a study conducted in 9 countries, including the UK, the USA, and China, showed that out of 24,410 cases:

- $78 \%$ had a fever (there is a gap in the indexes of different countries: in Korea, $32 \%$ of patients had a fever, in Singapore $72 \%)$

- $\quad 31 \%$ suffered from fatigue;

- $57 \%$ had coughing, but in Korea-18\%, in the Netherlands-76\%;

- $23 \%$ had difficult breathing [3].

others. One more characteristic, due to the shortterm practice of struggling with COVID-19, is the problem of testing contact persons. It is not clear why in Ukraine, on the basis of a certain three-level 
contact group, only the first level of people who were in direct contact with coronavirus patients is tested, ignoring other contact levels; however, testing contact persons after 14 days takes a lot of time, and within this period, the first-level contact person communicates with members of the family, and they, in turn, with other people, which conducts to the uncontrolled spread of the virus. According to the National Security and Defense Council, as of the morning of June 26, 41,117 cases of COVID-19 were registered in Ukraine. A record number of new COVID-19 - 1,109 cases have been identified in the past 24 hours. From the beginning of the pandemic in Ukraine, 1,110 people have died from coronavirus, 18,701 have recovered, and 22,254 people continue to be treated. According to the head of the Ministry of Health, the death rate from coronavirus in Ukraine is $2.6 \%$. The death rate in the United States is $5 \%$, Germany - $4 \%$, in Spain 9.5\% [4]. As for the situation with the pandemic in the world, as of June 26, 4,891 people died from the coronavirus. Of these, 736 were reported in Mexico; 1,055 victims in Brazil; 381 in India, and 663 in the United States. Regarding WHO, the development of an efficient treatment against COVID-19 will demand more than $\$ 31$ billion every year. Such a sorrowful situation pushed the Ukrainian authorities to take urgent anti-pandemic measures for protecting the population from the deadly disease; thus, due to the Resolution of the Cabinet of Ministers of Ukraine No. 211 of March 11, 2020 "On preventing the spread of the acute respiratory disease COVID-19 caused by the SARS-COV-2 coronavirus in Ukraine" (hereinafter referred to as the resolution), and taking into account the decision of the State Commission on Technogenic and Environmental Safety and Emergency Situations of March 10, 2020 [6], quarantine was introduced throughout Ukraine. According to the decree, on March 17, 2020, the authorities banned all mass events. Commercial, educational, catering, cultural, and religious events were also postponed, along with passenger transportation by road and rail in all types of inner communication. Already with the approval of the resolution of the Cabinet of Ministers of Ukraine No. 92 of May 20, 2020 "On the establishment of a quarantine to prevent the spread of the acute respiratory disease COVID-19 caused by the coronavirus SARS-CoV-2, and the stages of mitigating anti-epidemic measures" in accordance with part 5 of Article 4 of this resolution, the decision to mitigate anti-pandemic measures is taken and terminated in the region on the basis of the decision of the regional commission for technogenic and environmental safety and emergencies, which is approved taking into account the assessment of the epidemic situation and the presence of signs of anti-epidemic measures in the region. The decision to lessen the anti-epidemic measures is reviewed at least once every seven days, taking into account the results of the estimating of the current epidemic situation in a particular region [7].

Doubtlessly, all the mentioned and other terms on ensuring sanitary and hygienic and sanitary-antipandemic measures while quarantine will contribute to an active response to the COVID-19 pandemic: the population of Ukraine and the whole world will soon finally breathe freely after overcoming this deadly virus, the same way it was after the Spanish flu epidemic.

\section{Methodology and approaches to solving problems of administrative and legal principles for regulating the protection of human rights in the context of the spread of COVID-19 in Ukraine.}

At the same time, the question arises if international and domestic legislation is sufficiently regulated in the situation that has developed in connection with the emergence of quarantine, to what extent the quality of legislation meets modern requirements, and if there was such a public danger that led to the use of compulsory measures by the state to restrict human and civil rights. As for the quality of the law, we are impressed by the reasoned statement of the European Court of Human Rights in the case of Alexander Volkov v. Ukraine. "The quality of the law" means that national legislation must be accessible and predictable, that is, it must contain sufficient provisions to give people an adequate 
understanding of the circumstances and conditions under which public authorities have the right to take measures that affect the rights of individuals" [8]. For sure, all the mentioned questions can be partially answered by paragraph 11 of Part 1 of the European Social Charter (ESA), signed by the Governments of the Council of Europe in Strasbourg on 3 May 1996, which states that everyone has the right to apply measures to achieve the best possible state of health. Article 11 of the ECR supplements the above: "In order to ensure the effective realization of the right to health, the parties undertake, independently or in cooperation with public or private organizations, to take appropriate measures to prevent, to the extent possible, epidemic, endemic and other diseases, as well as accidents" [9]. No less important in the protection of human and civil rights is the provision of Article 6 of the European Charter of Patients ' Rights of Ukraine, which provides that everyone has the right to the confidentiality of personal information, including information about the state of health and possible diagnostic or therapeutic procedures, as well as the right to privacy during diagnostic examinations [10]. However, taking into account the problems of the study, the content of Articles 811 of the Convention for the Protection of Human Rights and Fundamental Freedoms of 4 November 1950 allows for a state of emergency to interfere with human rights "for the purpose of protecting health", and paragraph 1 of Article 15 of the Convention states that a High Contracting Party may take measures derogating from its obligations under this Convention only to the extent that this is caused by the seriousness of the situation, and provided that such measures are not contrary to other obligations under international law [11].

It is not surprising today that in the situation of the terrible COVID-19 plague, more than ten countries of the Council of Europe and other countries are to abandon some of the regulations of the Convention for the Protection of Human Rights and Fundamental Freedoms. But these exceptions should not allow encroachments of state bodies and private institutions, enterprises, and organizations on such basic inalienable human rights as
- the right to respect for private and family life;

- the right to life and health protection;

- the right to freedom of speech and thought;

- the right to protect personal data, including medical secrecy;

- the right to access information about the operation of public authorities;

- the right to work and entrepreneurship.

Especially unacceptable in the context of the COVID-19 epidemic is the disclosure of personal data about people with coronavirus disease, their addresses, and places of work in the media, as widely reported on Facebook, regarding the personal data of a woman who was the first to die from coronavirus in the Transcarpathian region, and the material was published in the Vesti publication with an infographic titled "Where in Kyiv was reported about COVID-19". This vicious practice, as international and domestic experience shows, can first of all lead to confrontation and destructive processes in society, which can manifest themselves in the form of panic and aggression on the part of the population. It is also disgusting to hear fake reports from politicians about cases of coronavirus disease of a political opponent. The "witch hunt" of those whose fear and aggression overwhelm the ability to think critically and weigh their actions does not stop. Commenting on this information, human rights activist, journalist, and coordinator of the project Without Borders Maxim Butkevich notes that the publication of Vesti was simply impressive. and not because the veil is lifted over the true scale of the spread of COVID-19 in Kyiv (this is not true), but as an example of a blatant violation-not only of human rights, but also of journalistic standards and legislation of Ukraine [12]. The Council of Independent Media also sharply criticized the violation of the human right to privacy in the context of quarantine, noting that "a journalist must find a balance between the public's right to information and the potential harm that this information can cause" [13].

\section{Administrative and legal principles for the protection of human rights}




\section{and the grounds for the disclosure of medical secrets in the conditions of COVID-19 quarantine}

It should be noted that the spread of the coronavirus epidemic in an emergency exacerbates legal relations related to the observance of the right to health secrecy. In accordance with Article 286 of the Civil Code of the Russian Federation, "an individual has the right to secrecy about the state of his health, the fact of seeking medical help, diagnosis, as well as information obtained during his medical examination. it is prohibited to request and provide information about the diagnosis and treatment methods of an individual at the place of work or study" [14]; however, given the problems of implementing certain regulations in the field of combating COVID-19, it would be desirable to supplement the provisions of Article 286 of the Civil Code with a list of circumstances in which deviation from this norm is possible in the interests of national security, economic prosperity, and human rights, as previously mentioned in part 1 of Article 32 of the Constitution of Ukraine. According to the second part of Article 6 of the Law of Ukraine of October 2, 1992, No. 2657-XII "On Information", the right to information may be restricted by law in the interests of national security, territorial integrity, or public order, to prevent riots or crimes, to protect the health of the nation, to protect the reputation or rights of other persons, to prevent the disclosure of confidential information, or to preserve the reputation and impartiality of justice. And the provision of part two of Article 11 of the law does not allow the collection, storage, use, and dissemination of confidential information about a person without his consent. The concept of confidential information includes, in particular, information about his citizenship, education, marital status, religious beliefs, health status, as well as address, date, and place of birth [15]. The obligation to provide administrative and legal protection of personal data of patients who are subject to the legislation on medical secrecy is based on paragraph 6 of part two of Article 7 of the Law of Ukraine "On Personal Data". Data protection "is the responsibility of medical personnel and others in the medical facility" Criminal liability for illegal disclosure of medical secrets as provided for in Article 145 of the Criminal Code of Ukraine; however, the Law of Ukraine of April 13, 2020 No. 555-IX "On Amendments to the Law of Ukraine" On Protection of the Population from Infectious Diseases in order to prevent the spread of coronavirus (COVID-19) provides that for the period of quarantine or restrictive measures related to the spread of coronavirus disease (COVID-19), and within 30 days from the date of its cancellation: "It is allowed to process personal data without the consent of the person, including data concerning the state of health, place of hospitalization or self-isolation; date of birth; place of residence, work (study); first name; last name; patronymic for countering the spread of coronavirus disease (COVID19), in the manner specified in the quarantine decision, provided that such data is used exclusively for antiepidemic measures. Within 30 days after the end of the quarantine period, such data must be depersonalized, and if impossible, destroyed" [16]. In the order of the Ministry of Health of Ukraine dated 13.03.2020 No. 663 "On the optimization of measures to prevent the penetration and spread of COVID-19 cases in Ukraine", which establishes recommendations for the actions of state institutions of regional and Kyiv laboratory centers of the Ministry of Health of Ukraine in detecting cases of COVID-19 on the basis of emergency information notification of these persons by the territorial body of the State Sanitary and Epidemiological Service of Ukraine by phone and, in particular, active identification of contact persons and transmission of this information to primary health care physicians (PHC)) to create active medical supervision-disclosure of information classified as a medical secret is officially allowed [17]. However, supporting the opinion of the public and journalists, the disclosure of personal data of patients, even those in quarantine, cannot be carried out solely on the basis of the interests of certain segments of society, these relations should be regulated by international and national legislation aimed at the administrative and legal protection of 
human and civil rights and freedoms enshrined in the Constitution of Ukraine. As for the international practice of disclosing medical secrets, in Germany, after the case when a pilot who suffered from depression and deliberately committed a plane crash in 2015, it was proposed to disclose medical secrets in the case when the patient is suspected of intending to commit a crime. American practice also shows that in the case of a dangerous infectious disease, it is allowed to disclose medical secrets on the basis of a court decision. Recently, in the United States and other countries, the idea of encouraging people with symptoms of coronavirus to voluntarily report their status in order to identify and test those with whom they come into contact has become widely popular; otherwise (disclosure of medical data without the consent of the carrier), most likely, changes in current legislation will be required, which requires a prompt response from parliament and the judiciary [18].

Administrative and legal principles of respect for human and civil rights in the field of entrepreneurship and issues of punishment of the population for violating the quarantine rules

VI. Unregulated administrative and legal issues of protection of human and civil rights in the field of entrepreneurship are of great importance during the quarantine period

The subjects of which have lost and continue to lose more and more investments and savings due to restrictive measures during the isolation period. The business circumstances associated with quarantine phenomena require the flexibility of business entities and the ability to make rapid changes in both national and global markets. And despite the benefits provided to quarantine subjects to regulate financial and tax relations, statistics show a sad picture in which enterprises face unforeseen everyday problems during the quarantine. So, according to the NBU, in April 2020, the business activity index fell below 30 points. "Business has almost stopped", the chairman of the National Bank said in an interview with BBC News Ukraine. According to a survey conducted by the European Business Association, this will take up to one year. $28 \%$ of companies have lost up to half of their revenue, $60 \%$ of companies are recovering from quarantine, and only $3 \%$ of companies have increased their revenue. More than a third lost up to $20 \%$ of their income, $18 \%$ - from half to three quarters; another $28 \%$ - up to half, and only one in ten companies lost nothing, and $3 \%$ of companies even increased their income [19]. 16\% of respondents said that they have already resumed work or have not stopped it at all. Most companies reported losses. With the adoption of the newly introduced Article 325 of the Criminal Code of Ukraine, related to the violation of the norms and rules established for the fight against mass noncommunicable diseases (poisoning) and the fight against them, if such actions caused or intentionally could cause the spread of these diseases, a number of legal issues arise. In particular, there is no difference between the composition of the administrative offense provided for in Article 44-3 of the Code of Administrative Offenses, and the composition of the specified crime and the number of fines; moreover, the norms and rules aimed at preventing epidemic and other infectious diseases under Article 325 of the Criminal Code of Ukraine without the introduction of a state of emergency violate international and constitutional human rights, which can lead to public discontent. Today, the process of implementing Article 44-3 of the Code of Administrative Offences of Ukraine, which was introduced on the basis of the Law of Ukraine of March 17, 2020, No. 530-IX "On Amendments to the Law of Ukraine" On Preventing the Occurrence and Spread of Coronavirus Disease (COVID - 19), continues [20]. As it turned out, the analysis of decisions under Article 44-3 of the Code of Administrative Offenses of Ukraine shows that judges in $90 \%$ of cases refuse to fine Ukrainians for violating quarantine rules. As of April 6, 2020, only 32 people out of 402 were found guilty and had to pay a fine for violating quarantine rules. In particular, 212 decisions on the materials of the case on bringing a person to administrative 
responsibility under Article 44-3 of the Administrative Code of Ukraine were returned to the GUNP of Ukraine for review, since the protocols on administrative offenses did not meet the requirements of Article 256 of the Code of Administrative Offenses of Ukraine, and most of the charges were based on evidence obtained illegally, as well as on assumptions [21]. For instance, the Zhovtnevy District Court of Zaporozhye closed the proceedings in case No. 331/1132/20 on April 6, 2020. The court found that the police officers did not provide the court with any evidence that the citizen under investigation consulted with the visitors face to face, and there were no explanations from witnesses-buyers, and the fact of the sale of goods was not recorded in any way. It was also argued that the open doors of the store could not indicate the reception of visitors for trade and serve as convincing and sufficient evidence of a violation of quarantine rules [22].

\section{Conclusion}

The progressive world and domestic community, taking into account the threat to human and civil rights in the context of overcoming the coronavirus, calls on state bodies to make reasonable, balanced, and, above all, decisions aimed at protecting these rights during the epidemic. Today, the main provisions of the Convention for the Protection of Human Rights and Fundamental Freedoms, the Convention on Human Rights, Biomedicine, National Emergency Legislation, as well as ways to respond to them, are more important than ever in the field of medicine. In particular, the main provisions of the conventions require equal access to health care for all people with limited resources, so that the most vulnerable segments of the population are not discriminated against; data collected to combat Covid-19 must be strictly regulated by law and aimed at protecting human rights; human rights restrictions must comply with legislation and be aimed at the collective interests and public health; the rights of persons involved in the development of treatment measures in crisis periods need special protection [23].
To sum up, administrative and legal measures to protect human and civil rights in the context of countering the spread of COVID-19 should be aimed at:

- protection from possible abuses by state and local authorities with the expansion of restrictive measures;

- developing a state strategy to counter the threat of the coronavirus epidemic in order to preserve the life and health of the population, prevent violations of human and civil rights, protect their honor, dignity, and identity;

- thorough scientific study of the administrative and legal mechanism for protecting human rights in quarantine and health care;

- respect for private life and health;

- awareness of the rights and guarantees of ensuring the life and health of the person under study;

- ensuring the adequacy and proportionality of the restrictions imposed to the threats posed by the emergency;

- provision of necessary material and medical assistance to elderly people who cannot independently cope with social protection issues during self-isolation.;

- adopting a codified act - a Medical code, the norms of which would regulate the relations between doctors and patients, the professional relations of doctors among themselves and with public authorities;

- protecting the rights of internally displaced persons by providing them with access to sanitation, personal hygiene, and medicines;

- improving the administrative and legal mechanism for the protection of human rights in the context of countering the spread of COVID-19 and in some other emergencies;

- generalizing judicial and administrative practices for the protection of human rights in the quarantine and medical spheres. 


\section{References}

[1]. Charter of Health Care Workers. LOBF "Medicine and Law". 2010. 112 p.

URL: http://zdorovia.ugcc.org.ua/hartiyapratsivnykiv-sluzhbyohorony-zdorov-ya/

[2]. UK News.

URL: http://www.polpred.ru/?ns=1\&cnt=31\&page $=4$

[3]. The most large-scale study: Scientists have named the main signs of coronavirus.

URL: https://golos.ua/i/758714

[4]. Mortality from coronavirus in Ukraine is $2.6 \%$, - Stepanov /

URL: https://112.ua/zdorovie/smertnostotkoronavirusa-v-ukrainesostavlyaet-26-stepanov540878.html

[5]. The world has set a new daily morbidity record for COVID-19.

URL:

https://www.pravda.com.ua/news/2020/06/27/7257 $\underline{359 /}$

[6]. On prevention of the spread on the territory of Ukraine of the acute respiratory disease COVID-19 caused by the coronavirus SARS-CoV2: Resolution of the Cabinet of Ministers of Ukraine № 211 of March 11, 2020

URL: https://zakon.rada.gov.ua/laws/show/2112020- \%D0\%BF\#Text

[7]. On the establishment of quarantine to prevent the spread of acute respiratory disease COVID-19 caused by coronavirus SARS-CoV-2 in Ukraine and the stages of mitigation of anti-epidemic measures: Resolution of the Cabinet of Ministers of Ukraine № 392 of May 20, 2020 URL: https://zakon.rada.gov.ua/laws/show/392- 2020$\% \mathrm{D} 0 \% \mathrm{BF} \# \mathrm{n} 192$

[8]. The case of Oleksandr Volkov v. Ukraine: judgment of the European Court of Human Rights of 27 May 2013 (Application № 21722/11).

URL:

https://ips.ligazakon.net/document/SOO00519

[9]. On the ratification of the European Social Charter: Law of Ukraine of 14 September 2006 №137-V.

URL: $\quad$ https://zakon.rada.gov.ua/laws/show/13716\#Text
[10]. European Charter of Patients' Rights in Ukraine.

URL:https://phc.org.ua/sites/default/files/uploads/f iles/hartia.pdf

[11]. Convention for the Protection of Human Rights and Fundamental Freedoms: Law of Ukraine $\begin{array}{llllll}\text { of } 17 \text { July } 1997 \quad \text { № } & 475 / 97 & \text { VR. }\end{array}$ URL:https://zakon.rada.gov.ua/laws/show/995 00 4?lang=en\#Text

[12]. Vesti broke the bottom, publishing the addresses of alleged patients with coronavirus in Kyiv.

URL:

https://detector.media/community/article/176234/2 020-04-08-vestiprobili-dno-publikuyuchiadresinachebto-khvorikh-na-koronaviruskiyan/ [13]. Statement of the NMR on the inadmissibility of publishing in the media the personal data of patients with coronavirus without their consent.

URL:

https://cedem.org.ua/news/zayavapublikatsia-

adres/

[14]. Civil Code of Ukraine. URL: https://zakon.rada.gov.ua/laws/show/435-

15? lang=en

[15]. On information: Law of Ukraine of October 2, 1992, № 2657-XII.

URL: https://zakon.rada.gov.ua/laws/show/265712\#Text

[16]. On Amendments to the Law of Ukraine ${ }^{3} \mathrm{On}$ Protection of the Population from Infectious Diseases' to Prevent the Spread of Coronavirus Disease (COVID-19): Law of Ukraine of April 13, 2020, № 555-IX.

URL: https://zakon.rada.gov.ua/laws/show/55520\#Text

[17]. On the optimization of measures to prevent the introduction and spread of cases of COVID-19 on the territory of Ukraine: order of the Ministry of Health of Ukraine dated 13.03.2020 № 663.

URL: $\quad$ https://moz.gov.ua/article/ministrymandates/nakaz-moz-ukraini-vid13032020--663-

pro-optimizacijazahodiv-schodonedopuschennjazanesennja-i-poshirennja-nateritorii-ukraini-vipadkiv-covid 19on.rada.gov.ua/laws/show/555-20\#Text 
[18]. Senyuta I.Ya. Medical secrecy in the conditions of COVID-19.

URL:

https://medcom.unba.org.ua/publications/5362-

likars-ka-taemnicya-vumovah-covid-19.html 